Diabetologia 9, 50-52 (1973)

(C) by Springer-Verlag 1973

\title{
Insulin Secretion in Down's Syndrome
}

\author{
M. Serrano-Ríos, C. San Roman Cos Gayon, M. T. Sordo, J. L. Rodriguez-Miñón \\ Departments of Metabolism and Genetics Fundación Jimenez Dią, Madrid, Spain
}

Recoived: October 18, 1972, accepted: Novomber 2, 1972

\begin{abstract}
Summary. Insulin secretion after oral (100 g) and i.v. glucose $(0.33 \mathrm{~g} / \mathrm{kg} \mathrm{b}$.w.) was studied in 14 patients with 21-trisomy (IDown's syndrome) and in 18 normal subjects. Plasma immunoreactive insulin (IRI), fasting and at predetermined time intervals during each glucose load, was measured by a double antibody method (Hales-Randle). Tolerance to oral glucoso in Down's patients was found to be normal though a flat, late peaked glycaemic response was characteristic of the group. Fusting IRI and insulin levels after oral glucose in patients did not significantly differ from those in the normal group. After i.v. glucose, the patients showod a slower decline of the blood sugar, maintaining significantly higher levels
\end{abstract}

than the normals at $30,40,50$ and 60 min after the glucose load. However, the peripheral glucose uptake expressed by the $\mathrm{K}$ index (Conard) did not significantly differ from the normal despite the lower $K$ values in the patients. Insulin release after $i . v$. glucose showed some differences botween both groups. - The present study cannot sup. port a causal relationship between D.M. and the 21 trisomy through an altered insulin secretion.

Key words: Normal group. Down's syndrome, mongoloid patients. Oral glucose tolerance test. Intravenous glucose tolerance test. Blood glucose. Immunoreactive insulin.

\section{Introduction}

The prevalence of Diabetes Mellitus (D.M.) in patients with Down's syndrome has been observed to be higher than in the general population $[1,2]$. A logical approach to this problem is to study the beta cell function in patients with Down's syndrome. In this communication we report the results obtained in the study of insulin secretion in a selected population of such patients.

\section{Material and Methods}

Material: Tho group of patients included 14 clinically and cytogenetically proven cases of Down's syndrome (primary 21 trisomy). All patients were attending a specialized institution on a part-time basis. None of them had a family history of D.M. The control group was composed of 18 healthy, nonobese, nondiabetic subjects with no family history of $D$. M. The characteristics of both groups are summarized in Table 1. A close matching betwoen thern was only possible with respect to age and sex.

Methods: Oral glucose tolerance test (O.G.T.T.) and rapid intratenous glucose tolerance test (I. V.G.T.T.) in patients and in normal subjects were performed exactly as described previously [3]. The O.G.T.T. was evalua.tod as proposed by Fajans and Conn [4] and the I.V.G.T.T. interpreted according to tho $K$ values as described by Conard [5]. Any drug therapy was discontinued in patients a woek before eachi test. Blood glucose (B.G.) was assayed in duplicato by the Hoffmann forricyanido method adapted to tho Tochnicon Autoanalyzer [6]. Plasma immunoreactive insulin (I. R.I.) was assayed in duplicate by the double antibody method of Halos and Randle [7]. The significance of the differences botween mean values in both groups was analyzed by Student's $t$ test.

\section{Results}

Mean values for B.G. and plasma I.R.I. during O.G.T.T. and I.V.G.T.T. in both groups are presented in Table 2. O.G.T.T.: as shown in the upper part of the table, the response in patients to the $100 \mathrm{~g}$ oral glucose load was well within the adopted criteria of normality [4]. However, the blood sugar levels in the patient group were significantly higher than those in the normals at $90(p<.005)$ and $120(p<.0005) \mathrm{min}$ after the glucose load. By contrast, I.R.I. response pattern in both groups was closely similar, with no statistically significant differences at any time interval. I.V.G.T.T.: B.G. values in the patient group were significantly higher (lower part, table 2) than in the normals at: $30(p<.05), 40(p<.001), 50(p<.001)$ and $60(p<.002)$ min after I. V.G.T.T. $(.33 \mathrm{~g}$ glucose/ $\mathrm{kg}$ body wght.). $\mathrm{K}$ values $(\overline{\mathrm{X}} \pm$ S.E.M.) were also lower in patients $(K=1.57 \pm 1.4)$ than in normals $(K=1.72 \pm 1.2)$, but the differences were not statistically significant $(p<.10)$.

I.R.I. values at fasting were similar in both groups, but the patients showed a secretory pattern different from that in the normal group. In fact, mean I.R.I. levels after i.v. glucose in the patients were significantly higher at $50(p<.05)$ and $60(p<.0025)$ min.

\section{Discussion}

Tolerance to glucose in Down's syndrome has been repeatedly studied $[2,8]$ but simultaneous investigation of insulin secretion is seldom encountered in the literature $[9,10]$. In older studies, thoroughly reviewed 
by Benda [11], qualitative and/or quantitative ab. normalities of carbohydrate tolerance in patients with Down's syndrome were reported. However, most of these studies lacked uniform criteria in the selection of patients as well as in the performance and interpretation of the tests. More recently, Milunsky $[2,12]$ has re-examined this problem with a very strict methodo- response to i. $\nabla$. glucagon and oral glucose. In our patients only minimal modifications in carbohydrate tolerance and insulin secretion were discovered. During O.G.T.T. no truly abnormal giycaemic response was present in individual patients, but a flat and late peaked glycaemic curve characterized the group. In agreement with the above mentioned studies [10] no

Tablo 1. Patients and Normal subjects. Characteristics of both groups

\begin{tabular}{|c|c|c|c|c|c|c|c|}
\hline & \multirow[t]{2}{*}{$N$} & \multicolumn{2}{|c|}{ Sex } & \multirow{2}{*}{$\begin{array}{l}\text { Age (years) } \\
\begin{array}{l}\text { Mean } \\
\text { (range) }\end{array} \\
\end{array}$} & \multirow{2}{*}{$\begin{array}{l}\begin{array}{l}\text { Body weight } \\
\text { (kg) }\end{array} \\
\begin{array}{l}\text { Mean } \pm \text { S.E.M. } \\
\text { (range) }\end{array}\end{array}$} & \multirow{2}{*}{$\begin{array}{l}\text { Height (cm) } \\
\begin{array}{l}\text { Mean } \pm \text { S. E.M. } \\
\text { (range) }\end{array}\end{array}$} & \multirow{2}{*}{$\begin{array}{l}\begin{array}{l}\text { Body surface } \\
\text { (sqm) }\end{array} \\
\begin{array}{l}\text { Mean } \pm \text { S. E. M } \\
\text { (range) }\end{array}\end{array}$} \\
\hline & & F & $\mathbf{M}$ & & & & \\
\hline $\begin{array}{l}\text { Normal } \\
\text { group. }\end{array}$ & 18 & 6 & 12 & $\begin{array}{l}21 \\
(16-26)\end{array}$ & $\begin{array}{l}66.5 \pm 2.2 \\
(52-82)\end{array}$ & $\begin{array}{c}1.71 \pm 1.8 \\
(1.57-1.82)\end{array}$ & $\begin{array}{l}1.77 \pm 3.7 \\
(1.54-2)\end{array}$ \\
\hline Patients & 14 & 6 & 8 & $\begin{array}{l}18 \\
(13-24)\end{array}$ & $\begin{array}{l}49.7 \pm 3.5 \\
(31-68)\end{array}$ & $\begin{array}{c}1.49 \pm 1.9 \\
(1.38-1.61)\end{array}$ & $\begin{array}{l}1.41 \pm 6 \\
(1.11 \pm 1.72)\end{array}$ \\
\hline
\end{tabular}

Table 2. Blood glucose (B. G. mgs\%) and Plasma Immunoreactive Insulin (I.R.I. $\mu U / m l$ ) in normals and Down's patients during O.G.T.T. (100 g of glucose) and I.V.G.T.T. (.33 g glucose $/ \mathrm{kg}$ body weight). Values are X \pm S.E.M. Number of subjects in parentheses

Time: minutes

\begin{tabular}{|c|c|c|c|c|c|c|c|c|c|c|}
\hline Test & Group & \multicolumn{2}{|c|}{ Determinations } & 0 & 15 & $\mathbf{3 0}$ & 60 & \multicolumn{2}{|c|}{90} & 120 \\
\hline \multirow{4}{*}{ O.G.T.T. } & \multirow[t]{2}{*}{ Normals } & $\begin{array}{l}\text { B. G. } \\
(\mathrm{mg} \%)\end{array}$ & & $\begin{array}{l}78.2 \\
\pm 1.5 \\
(18)\end{array}$ & $\begin{array}{r}92.1 \\
\pm \quad 2.7 \\
(18)\end{array}$ & $\begin{array}{c}112.8 \\
\pm \quad 4.2 \\
(18)\end{array}$ & $\begin{array}{c}105.4 \\
\pm \quad 4.5 \\
(18)\end{array}$ & & & $\begin{array}{r}79.3 \\
+\quad 1.6 \\
(18)\end{array}$ \\
\hline & & $\begin{array}{l}\text { I.R.I. } \\
\mu \mathrm{U} / \mathrm{ml}\end{array}$ & & $\begin{array}{l}24.9 \\
+3.4 \\
(11)\end{array}$ & $\begin{array}{r}56.7 \\
+\quad 6.2 \\
(12)\end{array}$ & $\begin{array}{r}114.2 \\
\pm 13.9 \\
(12)\end{array}$ & $\begin{array}{c}147.1 \\
+18.2 \\
(10)\end{array}$ & & & $\begin{array}{r}87.0 \\
+13.5 \\
(11)\end{array}$ \\
\hline & \multirow{2}{*}{$\begin{array}{l}\text { Down's } \\
\text { patients }\end{array}$} & $\begin{array}{l}\text { B.G. } \\
(\mathrm{mg} \%)\end{array}$ & & $\begin{array}{l}79.3 \\
\pm 2.6 \\
(14)\end{array}$ & $\begin{array}{r}95.5 \\
+\quad 3.6 \\
(14)\end{array}$ & $\begin{array}{r}112.2 \\
\pm \quad 7.9 \\
(14)\end{array}$ & $\begin{array}{r}108.0 \\
\pm \quad 7.6 \\
(14)\end{array}$ & \multicolumn{2}{|c|}{$\begin{array}{r}100.5 \\
\pm \quad 4.0 \\
(14)\end{array}$} & $\begin{array}{r}95.8 \\
\pm \quad 3.5 \\
(14)\end{array}$ \\
\hline & & $\begin{array}{l}\text { I.R.I. } \\
\mu \mathrm{U} / \mathrm{ml}\end{array}$ & & $\begin{array}{l}29.6 \\
\pm 3.1 \\
(14)\end{array}$ & $\begin{array}{r}81.9 \\
\pm 18.9 \\
(10)\end{array}$ & $\begin{array}{r}134.0 \\
\pm 24.1 \\
(13)\end{array}$ & $\begin{array}{c}135.1 \\
\pm 24.1 \\
(14)\end{array}$ & \multicolumn{2}{|c|}{$\begin{array}{r}146.0 \\
\pm 24.9 \\
(11)\end{array}$} & $\begin{array}{r}114.2 \\
\pm 21.9 \\
(9)\end{array}$ \\
\hline Test & Group & $\begin{array}{l}\text { Deter- } \\
\text { minations }\end{array}$ & 0 & 5 & 10 & 20 & 30 & 40 & 50 & 60 \\
\hline \multirow{4}{*}{ IVGTT } & \multirow[t]{2}{*}{ Normals } & $\begin{array}{l}\text { B. G. } \\
(\mathrm{mg} \%)\end{array}$ & $\begin{array}{l}77.2 \\
+1.5 \\
(18)\end{array}$ & $\begin{array}{c}263.11 \\
\pm \quad 9.6 \\
(18)\end{array}$ & $\begin{array}{r}181.5 \\
\pm 10.7 \\
(18)\end{array}$ & $\begin{array}{c}129.1 \\
\pm \quad 4.6 \\
(18)\end{array}$ & $\begin{array}{r}99.5 \\
+\quad 4.2 \\
(18)\end{array}$ & $\begin{array}{r}88.5 \\
\pm \quad 3.8 \\
(17)\end{array}$ & $\begin{array}{l}80.7 \\
\pm 3.6 \\
(17)\end{array}$ & $\begin{array}{l}73.6 \\
\pm 2.5 \\
(18)\end{array}$ \\
\hline & & $\begin{array}{l}\text { I.R.I. } \\
\mu \mathrm{U} / \mathrm{ml}\end{array}$ & $\begin{array}{l}26.6 \\
+3.01 \\
(15)\end{array}$ & $\begin{array}{c}103.7 \\
+15.3 \\
(14)\end{array}$ & $\begin{array}{r}92.4 \\
+12.7 \\
(15)\end{array}$ & $\begin{array}{c}69.6 \\
+10.0 \\
(15)\end{array}$ & $\begin{array}{r}56.6 \\
\pm \quad 5.9 \\
(14)\end{array}$ & $\begin{array}{r}49.4 \\
+\quad 5.7 \\
(13)\end{array}$ & $\begin{array}{l}38.6 \\
\pm 6.2 \\
(13)\end{array}$ & $\begin{aligned} & 28.9 \\
& \pm 3.6 \\
&(14)\end{aligned}$ \\
\hline & \multirow{2}{*}{$\begin{array}{l}\text { Down's } \\
\text { patients }\end{array}$} & $\begin{array}{l}\text { B.G. } \\
(\mathrm{mg} \%)\end{array}$ & $\begin{array}{l}78.6 \\
+2.6 \\
(13)\end{array}$ & $\begin{array}{c}211.4 \\
\pm 21.7 \\
(10)\end{array}$ & $\begin{array}{c}186.4 \\
+10.5 \\
(11)\end{array}$ & $\begin{array}{c}141.0 \\
+\quad 9.9 \\
(12)\end{array}$ & $\begin{array}{c}115.3 \\
\pm \quad 5 \\
(11)\end{array}$ & $\begin{array}{c}111.0 \\
\pm \quad 7.4 \\
(13)\end{array}$ & $\begin{array}{r}103.4 \\
\pm 7.5 \\
(12)\end{array}$ & $\begin{array}{l}97.7 \\
\pm 7 \\
(13)\end{array}$ \\
\hline & & $\begin{array}{l}\text { I. R.I. } \\
\mu \mathrm{U} / \mathrm{ml}\end{array}$ & $\begin{array}{c}28.7 \\
\pm 2.5 \\
(10)\end{array}$ & $\begin{array}{c}138.4 \\
\pm 21.7 \\
(10)\end{array}$ & $\begin{array}{r}104.8 \\
\pm \quad 4.3 \\
(7)\end{array}$ & $\begin{array}{r}70.5 \\
+\quad 5.9 \\
(9)\end{array}$ & $\begin{array}{r}77.6 \\
\pm 11.4 \\
(9)\end{array}$ & $\begin{array}{r}65.8 \\
+10.2 \\
(8)\end{array}$ & $\begin{array}{r}55.0 \\
\pm 5.5 \\
(9)\end{array}$ & $\begin{array}{l}57.3 \\
\pm 8.2 \\
(10)\end{array}$ \\
\hline
\end{tabular}

logical approach. Using epidemiological criteria, Burch and Milunsky [13] suggested the hypothesis that an auto-immune damage of the pancreatic beta cell could underlie the peculiar affinity of D.M. for the patients with Down's syndrome. However, studies by Milunsky, Marks and Samols [9] and by Milunsky and others [10] failed to uncover definite abnormalities in the insulin abnormalities in insulin release were found after the oral glucose load. With the I.V.G.T.T. a relatively decreased glucose utilization, with a more persistent insulin release, was present in the patient group. These findings could perhaps suggest some kind of peripheral resistance to insulin action, but it should not be forgotten that the underdeveloped body mass of the 
Down's patients could be an important factor in deter. mining those subtle differences from the normal population. Therefore, our present results do not reveal any clearcut impact of the genetic imbalance caused by the 21-trisomy upon the functional capacity of the beta cell that could be linked with the high incidence of D.M. in that disease.

\section{References}

1. Farquhar, J.W.: Diabetic children in Scotland and the need for care. Scot. Med. J. 7, 119-123 (1962).

2. Milunsky, A., Neurath, P.W.: Diabetes mellitus in Down's syndrome. Archs. Envir. Hith. 17, 372-376 (1968).

3. Serrano-Ríos, M., Ramos, F., Rodriguez-Miñón, J.L., Vivanco, F.: Studies in Prediabetes. Insulin response to oral glucose, Intravenous Tolbutamide and Rapid Intravenous glucose infusion in genetic prediabetics. Diabetologia 6, 392-398 (1970).

4. Fajans, S.S., Conn, J.W.: Prediabetes, Subclinical Diabetes and latent chemical Diabetes. Interpreta. tion, Diagnosis and Treatment. In: "On the Nature and Treatment of Diabetes Mellitus". Chapter 46, pp. 641 - 656. Editors: Leibel, B.S., Wrenshall, G.A. Amsterdam, New York : Excerpta Medica Foundation, 1965.

5. Conard, V., Franckson, J.R.M., Bastenie, P.A., Kestens, J., Kóvac8, L.: Etude critique du triangle d'hyperglycemie intraveineux chez l'homme normal et determination d'un "coefficient d'assimilation glu- cidique". Arch. int. Pharmacodyn. 13, 277--292 (1953).

6. Hoffmann, W.S.: A rapid photoolectric mothod for the determination of glucose in blood and urine. $J$. biol. Chem. 120, $51-55$ (1937).

7. Hales, C.N., Randle, P.J.: Immunoassay of insulin with insulin-antibody procipitate. Biochem. J. 88, $137-146$ (1963).

8. Runge, G.H.: Glucose tolerance in Mongolism. Amer. J. ment. Defic. 47, $822-828$ (1959).

9. Milunsky, A., Marks, V., Samols, E.: Insulin and glucose response to glucagon in Down's syndrome. Letter to the Editor. The Lancet 1967 II, $1093-1094$.

10. Milunsky, A., Lowy, C., Rubenstein, A.H., Wright, A.D.: Carbohydrate tolerance, growth hormone and insulin levels in mongolism. Develop. Mod. Child. Neurol. 10, 25-31 (1968).

11. Benda, C.E.; Down's syndrome. Mongolism and its management, pp. 109-117. New York, London: Grune and Stratton 1969.

12. Milunsky, A.: Glucose intolerance in the parents of children with Down's syndrome. Amer. J. ment. Defic. 74, 475-478 (1970).

13. Burch, P.R.J., Milunsky, A.: Early onset Diabetes mellitus in the general and Down's syndrome populations. Genetics, Etiology and Pathogenesis. Hypothesis. The Lancet 1969 I, $554-558$.

J.L. Rodriguez-Miñon
Clinica de Nuestra
Señora de la Concepcion
Ciudad Universitaria
Av. Reyes Catolicos 2
Madrid
Spain

